\title{
Thermal Process Integration in the AVDU A12/2 Crude Distillation Unit during Winter Operation
}

\author{
L. L. Tovazhnyanskii ${ }^{a}$, P. A. Kapustenko ${ }^{a}$, L. M. Ul'ev', S. A. Boldyrev ${ }^{a}$, \\ O. P. Arsen'eva ${ }^{a}$, and M. V. Tarnovskii ${ }^{b}$ \\ ${ }^{a}$ Kharkov Polytechnic Institute, National Technical University, Kharkov, Ukraine \\ ${ }^{b}$ OptimEnergo Energy Service Firm, Kharkov, Ukraine \\ email: ulyevlm@mail.ru \\ Received June 15, 2009
}

\begin{abstract}
A pinch analysis of the AVDU A12/2 crude distillation unit processing 2 million tons of crude oil per year is made. A pinch retrofit of the recuperative heat-exchange system of the unit is performed. It is shown that the implementation of the proposed project will reduce the arbitrary energy consumption by $60 \%$, which corresponds to a reduction in specific fuel consumption from 36 to $13 \mathrm{~kg}$ per ton of refined oil.
\end{abstract}

DOI: $10.1134 / \mathrm{S} 0040579509060086$

Reduction in the consumption of fuel and power resources in industry can be achieved by the wide implementation of modern energy-saving technologies and the creation of highly efficient power engineering complexes. Although this challenge is far from being new for the petrochemical industry, two factors appeared in the last two decades which attached special significance to energy saving in CIS countries and prompted the extension of the range of methods and devices used for this purpose.

First, the rise in energy prices has encouraged more saving of energy to reduce total costs. Moreover, the operation of all of the plants designed and built in the time of low energy prices is currently far from optimal in terms of energy consumption.

Second, the rate of economic growth has significantly decreased, and, therefore, so has the potential of putting new plants into operation and implementing new processes; therefore, more and more attention is shifted towards increasing the efficiency of using existing equipment.

Oil refining and petrochemical production are energy intensive, and energy consumption considerably affects the production cost. Depending on the degree of oil conversion, oil composition, the range and quality of products, equipment performance, and other factors, auxiliary energy consumption by refineries is equivalent to $6-10 \%$ of refined oil. Of the total energy consumption, 55-65\% is for process fuel, $30-35 \%$ is for heat, and $8-12 \%$ is for electric power [1].

The most energy-intensive processes are hydrocracking, catalytic cracking and reforming, coking, and the production of oil. Crude distillation processes are less energy intensive, but all of the crude oil entering a refinery is subjected to atmospheric/vacuum distillation, which takes up about $50 \%$ of the total energy consumption. Consequently, a reduction of energy consumption is equally important for all oil-refining processes. The most energy-intensive petrochemical production processes are the syntheses of lower olefins, methanol, hydrogen, and aromatic hydrocarbons.

The energy consumption by modern non-CIS oil refineries is $3000-3500 \mathrm{MJ}$, or $100-114 \mathrm{~kg}$ of standard fuel per ton of refined oil. For CIS oil refineries, the energy consumption in terms of standard fuel is approximately the same, but the degree of oil conversion is much lower. With an increase in the degree of oil conversion and an expansion of petrochemical production, the energy consumption increases, and so does the importance of energy saving. The main ways of improving the competitiveness of CIS oil refining and petrochemical production are to increase the degree of oil conversion and significantly reduce the energy consumption by all of the processes [2].

In CIS oil refineries, most of the processing units were constructed in the 1960s-1970s, when the cost of energy resources was very low and energy saving was of little consequence, and almost no energy-saving arrangements were undertaken. Therefore, the energy consumption by the basic oil refining and petrochemical production processes in these processing units is $30-60 \%$ higher than that in modern units with significant thermal processes integration.

The specific energy consumption can be reduced by upgrading individual production systems, units, and plants and by rationalizing and improving production processes.

Previously [3], we designed a project of partial process integration in a crude distillation unit of the Kremenchug Oil Refinery in Ukraine. It was shown that the implementation of the process retrofit project designed by pinch analysis methods can reduce the consumption of hot and cold 
utilities by 9 and $12 \%$, respectively. However, in that work, the decrease in the number of external utilities fed to the distillation process was only determined without analyzing their production, i.e., without considering the heating of crude oil and its products in a pipe still; moreover, the thermal process integration covered only some of the process flows in the unit.

It was also shown [4] that energy saving due to measures designed by pinch analysis in three European oil refineries of a small scale of $\sim 20000-50000 \mathrm{t}$ of crude oil per year is $\$ 13.7$ million per year. Using pinch analysis methods in the Guangdong Oil Refinery in China, \$16 million was saved per year owing to an increase in the energy efficiency of the plant, making this oil refinery one of the world's best oil refineries (3\%) [5].

The retrofitting of an oil refinery in Indonesia by pinch analysis led to a reduction in energy consumption by $39 \%$ with a 6-month return on investment [6].

It was demonstrated $[7,8]$ that using pinch analysis methods in the design of recuperative heat-exchange systems for crude distillation units can reduce the consumption of hot and cold utilities by 29 and 34\%, respectively.

In this work, we perform a pinch analysis of the system of process flows in one of the early crude distillation units, the A12/2 atmospheric/vacuum distillation unit (AVDU), designed in 1956 and upgraded for refining 2 million tons of oil per year in 1967. Here, we make a pinch analysis of only one of the operating modes of the unit, namely, the mode of winter operation of A12/2 with a vacuum section.

\section{PINCH ANALYSIS AND INTEGRATION}

This plant currently uses a countercurrent pattern of heat recuperation, which is typical of the 1970s and is generally not optimal for large systems of heat exchangers [3].

We analyzed four operating modes of the unit: operation with and without a vacuum section in winter and summer. Figure 1 presents a flow sheet of the A12/2 unit with a vacuum section.

A flow of crude oil at ambient temperature is fed to the unit where it is split into two flows, each being heated in a series of heat exchangers and delivered through a mixer to a first-stage electric dehydrator (Fig. 1). Then, partially desalted oil is conveyed to a second-stage electric dehydrator. After the dehydrators, desalted dehydrated oil enters columns $\mathrm{C} 1$ and $\mathrm{Cla}$ in two flows, in each of which a part of the oil flow is heated in a pipe still and the other part is heated by the separation products in shell-and-tube heat exchangers.

Stripped oil from the bottom of columns $\mathrm{C} 1$ and $\mathrm{C} 1 \mathrm{a}$ at a temperature of $200-250^{\circ} \mathrm{C}$ is fed to the coils of pipe stills PS1 and PS2. A tail fraction of gasoline and diesel fuel in the vapor phase from the top of columns $\mathrm{C} 2$ and $\mathrm{C} 2 \mathrm{a}$ is transferred through vapor lines to column C3.

A fraction of distillate oil and diesel fuel enters the top section of stripping column C5/1, from which the flow is delivered through circulation reflux heat exchangers to columns $\mathrm{C} 2$ and $\mathrm{C} 2 \mathrm{a}$.
Vapors from the stripping section of column $\mathrm{C} 5 / 1$ enter tray 16 of column C3. From trays 11 and 13 of column C2 and trays 9, 11, and 13 of column C2a, atmospheric gasoil can be removed; it is fed to the stripping section of stripping column $\mathrm{C} 5 / 3$, from which it is taken by a vapor pump and pumped into diesel fuel or fuel oil. Vapors from the stripping section of stripping column C5/3 enter columns $\mathrm{C} 2$ and $\mathrm{C} 2 \mathrm{a}$.

The tail gasoline fraction is distilled from the top of column C3. Gasoline vapors enter through the vapor lines to condensers and gas separators, and then gasoline flows by gravity to a buffer vessel.

Diesel fuel from the bottom of column C3 is pumped through heat exchangers to a pool. If there is a vacuum section, part of the fuel oil from the bottom of columns $\mathrm{C} 2$ and $\mathrm{C} 2 \mathrm{a}$ is pumped through the vacuum coil of pipe still PS1, where it is heated to a temperature of $\sim 380-420^{\circ} \mathrm{C}$, to vacuum column C4. Fuel oil from the bottom of column C2 can be directed to flow by gravity through a bypass line to vacuum column $\mathrm{C} 4$.

In vacuum column $\mathrm{C} 4$, a wide fraction-vacuum gasoil-is distilled from fuel oil. Vacuum gasoil is then pumped through heat exchangers to a pool.

Vacuum gasoil can be delivered to fuel oil. Water vapor and a part of the oil gases from the top of the vacuum receiver enter a barometric condenser and are condensed using vacuum gasoil.

The temperatures and flow rates of all the process flows in the unit and the flows of the utility system were measured with both stationary and mobile instruments. The properties of the flue gases of the utility system were measured with gas analyzers and pyrometers. Data on the thermophysical properties of the products of the process flows at the moments of time of the measurements were obtained from the Central Plant Laboratory.

After classifying the material and heat balances of the unit on the basis of the collected data, the flow data necessary for integration were summarized in a flow table. In most of the process flows, there are either phase transitions or the specific heats significantly change within the ranges of temperature variations; therefore, for further processing, the data were segmented according to their temperature ranges. In each of such intervals, the properties of a flow can be considered as constant [9].

A comparison of the energy consumption by the unit in winter and summer at the same production capacity with consideration for the difference between the temperatures of crude oil supplied from the storage tanks revealed significant heat losses to the environment. Therefore, the temperatures of all of the open surfaces of the transport system and the heat-exchange equipment were measured. The measurement results allowed us to calculate the heat losses to the atmosphere by convection and radiation. These losses amounted to $8 \mathrm{MW}$, from which only the losses from the heat-exchange system constituted about $6 \mathrm{MW}$.

The power released from the air and water coolers and the heat loss power withdrawn with the flue gases were measured, as were the temperatures of the heat- 


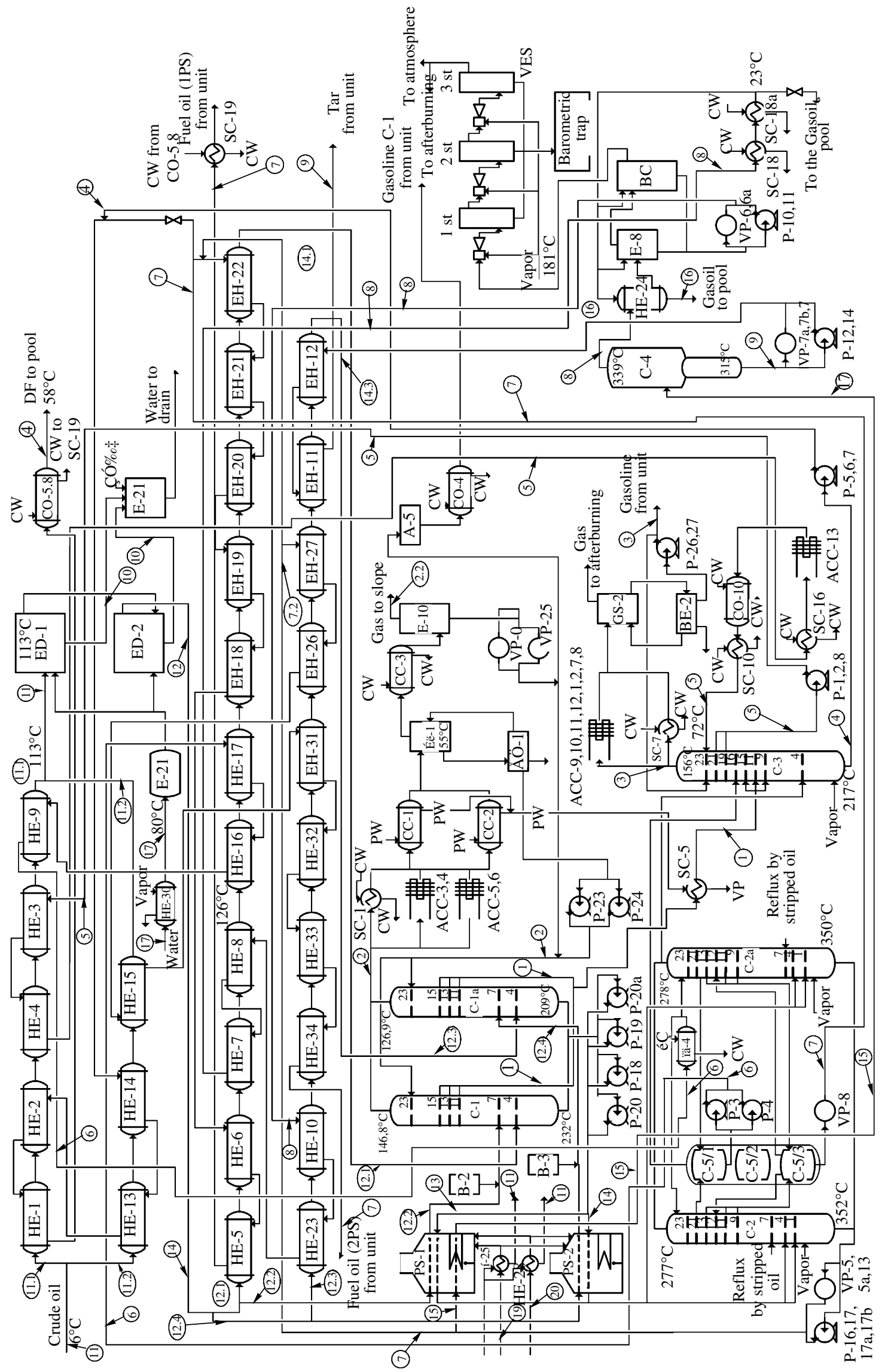




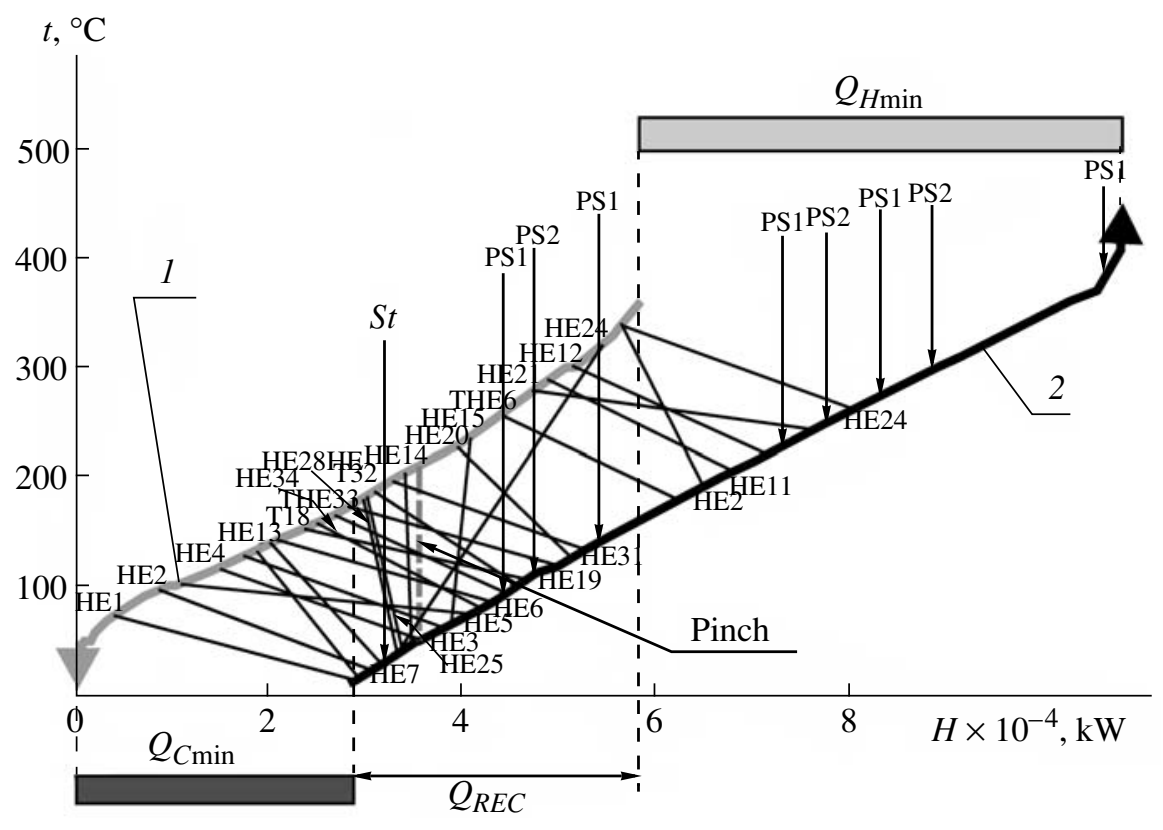

Fig. 2. Composite curves for crude distillation in the AVDU A $12 / 2$ unit with the current heat recuperation system $\left(Q_{H \min }=\right.$ 49.8 MW, $Q_{C \min }=28.1 \mathrm{MW}, Q_{R E C} \approx 30 \mathrm{MW}$ ): (1) composite curve for hot flows and (2) composite curve for cold flows (St, steam heater; PS1, PS2, pipe stills; HE1-HE34, heat exchangers).

transfer media in each working heat exchanger. This allowed us to calculate the recuperation power in the heat-exchange system in terms of both hot and cold flows. The two values differ by the heat losses from the heat-exchange system of the unit.

The parameters of the flows in the pipe stills, which were necessary for calculating the payload in the utility system, were measured. The calculation showed that the payload in the pipe still was $~ 50 \mathrm{MW}$.

The formulation of the material and heat balances of the unit and the extraction of the data on the process flows allowed us to construct composite curves $[9,10]$ of the process flows of the unit (Fig. 2). The relative positions of the composite curves for the hot and cold utilities were determined using both the utility measurement data (the power consumed by the process from the hot utilities and the power withdrawn from the process by the cold utilities), and the results of measuring the temperatures and flow rates of the heat-transfer media in the heat-transfer equipment.

The composite curves contain much information on the system of process flows, the utility system, and the efficiency of using heat in the process.
The projection of the composite curve for the hot utilities to the enthalpy (abscissa) axis presents the heat power that can be withdrawn from the system of hot flows and can be used to heat the cold process flows. This value is 59.09 MW. Similarly, the projection of the composite curve for the cold utilities to the enthalpy axis shows the heat power that should be supplied to the cold flows to perform crude distillation in the AVDU A12/2 unit.

Performing the process requires a power of $\sim 79.8 \mathrm{MW}$, but this means that all of this power must be obtained from the utility system of the unit, in our case, from the system of pipe stills. Part of the energy may be recuperated using the system of heat exchange between the cold and hot flows. The power is shown by the span between the curves (Fig. 2). The recuperation power in the heat-exchange system is $Q_{R E C} \approx 30 \mathrm{MW}$.

The heat power consumed by the process from the utilities is $Q_{H \min } \sim 49.8 \mathrm{MW}$, and the load on the cold utilities is $Q_{C \min } \sim 28.1 \mathrm{MW}$.

The pinch is located at temperatures of hot and cold flows of $t_{\text {Phot }}=210^{\circ} \mathrm{C}$ and $t_{\text {Pcold }}=50^{\circ} \mathrm{C}$, respectively, and $\Delta T_{\min }=160^{\circ} \mathrm{C} \cdot \Delta t_{\min }$ in this case is not the minimal dif-

Fig. 1. Flow sheet of the AVDU A12/2 crude distillation unit with the current heat recuperation system. The numbers within the columns are the numbers of trays. The numbers of flows are taken according to the table. The temperatures in the columns are the temperatures of the bottom and top trays, respectively. A, BU, B, E, BE, vessels; ACC, air-cooled condenser; AVDU, atmospheric/vacuum distillation unit; $\mathrm{BC}$, barometric condenser; $\mathrm{C} 1, \mathrm{C} 1 \mathrm{a}$, atmospheric distillation columns; $\mathrm{C} 2, \mathrm{C} 2 \mathrm{a}$, columns for the distillation of stripped oil; C3, distillation column for the production of diesel oil; C4, vacuum column; C5, stripping column; CC, cooler-condenser; CO, cooler; CW, cooling water; DF, diesel fuel; ED, electric dehydrator; EDU, electric desalting unit; GS, gas separator; HE1-HE34, heat exchangers; P, pump; PS, pipe still; PW, process water; SC, submerged cooler; VES, vapor ejection section; VP, vapor pump. 
Properties of process flows involved in process integration for the winter operation of AVDU A12/2 with a vacuum section

\begin{tabular}{|c|c|c|c|c|c|c|c|c|c|c|}
\hline No. & Flow & Type & ${ }^{{ }^{{ }} \mathrm{C}}$ & $\begin{array}{l}t_{T}, \\
{ }^{\circ} \mathrm{C}\end{array}$ & $\begin{array}{l}G, \\
\mathrm{t} / \mathrm{h}\end{array}$ & $\begin{array}{c}C, \\
\mathrm{~kJ} /\left(\mathrm{kg}^{\circ} \mathrm{C}\right)\end{array}$ & $\begin{array}{c}r, \\
\mathrm{~kJ} / \mathrm{kg}\end{array}$ & $\begin{array}{c}C_{P S}, \\
\mathrm{~kW} /{ }^{\circ} \mathrm{C}\end{array}$ & $\begin{array}{l}\Delta H, \\
\mathrm{~kW}\end{array}$ & $\begin{array}{c}\alpha, \\
\mathrm{kW} /\left(\mathrm{m}^{2}{ }^{\circ} \mathrm{C}\right)\end{array}$ \\
\hline 1 & Crossflow from $\mathrm{C} 1, \mathrm{C} 1 \mathrm{a}$ to $\mathrm{C} 3$ & $\mathrm{~A}^{*}$ & 173 & 54 & 8.20 & 2.11 & - & 4.81 & 571.93 & 0.40 \\
\hline 2.1 & Gasoline vapor cooling in $\mathrm{C} 1, \mathrm{Cla}$ & A & 145 & 50 & 29.69 & 2.52 & - & 20.78 & 1974.36 & 0.10 \\
\hline 2.2 & Cooling of gas from $\mathrm{C} 1, \mathrm{C} 1 \mathrm{a}$ & $\mathrm{A}$ & 145 & 40 & 2.78 & 2.52 & - & 1.95 & 204.33 & 0.10 \\
\hline 2.3 & Gasoline vapor condensation in $\mathrm{C} 1, \mathrm{Cla}$ & A & 50 & 50 & 29.69 & - & 75 & - & 618.53 & 1 \\
\hline 2.4 & Cooling of gas from $\mathrm{C} 1, \mathrm{Cla}$ & A & 50 & 40 & 29.69 & 2.11 & - & 17.40 & 174.01 & 0.40 \\
\hline 3.1 & Gasoline vapor cooling in C3 & A & 157 & 46 & 17.40 & 2.52 & - & 12.18 & 1351.98 & 0.10 \\
\hline 3.2 & Gasoline vapor condensation in C3 & A & 46 & 46 & 17.40 & - & 75 & - & 362.50 & 1 \\
\hline 3.3 & Water vapor cooling in C3 & A & 157 & 100 & 1.05 & 2.00 & - & 0.58 & 32.96 & 0.12 \\
\hline 3.4 & Water vapor condensation in $\mathrm{C} 3$ & A & 100 & 100 & 1.05 & - & 2256 & - & 658.00 & 2 \\
\hline 3.5 & Water cooling in C3 & A & 100 & 46 & 1.05 & 4.19 & - & 1.22 & 65.99 & 0.80 \\
\hline \multirow[t]{3}{*}{4} & Diesel fuel & A & 229 & 200 & 71.11 & 2.70 & - & 68.29 & 1980.27 & 0.20 \\
\hline & & A & 200 & 100 & 71.11 & 2.42 & - & 58.81 & 5880.67 & 0.20 \\
\hline & & A & 100 & 58 & 71.11 & 2.10 & - & 51.76 & 2174.05 & 0.20 \\
\hline 5 & Central reflux in C3 & $\mathrm{A}$ & 165 & 74 & 75.79 & 2.11 & - & 55.87 & 5083.79 & 0.15 \\
\hline 6 & Central reflux in $\mathrm{C} 2, \mathrm{C} 2 \mathrm{a}$ & A & 295 & 144 & 30.73 & 2.11 & - & 29.85 & 4507.90 & 0.15 \\
\hline \multirow[t]{5}{*}{7} & Fuel oil & A & 360 & 300 & 79.79 & 2.90 & - & 89.94 & 5396.67 & 0.15 \\
\hline & & A & 300 & 250 & 79.79 & 2.71 & - & 81.41 & 4070.55 & 0.15 \\
\hline & & A & 250 & 200 & 79.79 & 2.54 & - & 73.74 & 3687.10 & 0.15 \\
\hline & & A & 200 & 150 & 79.79 & 2.36 & - & 65.87 & 3293.68 & 0.15 \\
\hline & & A & 150 & 90 & 79.79 & 2.17 & - & 57.37 & 3442.40 & 0.15 \\
\hline 8.1 & Vacuum gasoil & A & 330 & 300 & 43.96 & 2.52 & - & 30.77 & 923.16 & 0.40 \\
\hline 8.2 & Vacuum gasoil vapor condensation & A & 300 & 300 & 43.96 & - & 75 & - & 915.83 & 1 \\
\hline \multirow[t]{3}{*}{8.3} & Vacuum gasoil cooling & A & 300 & 200 & 43.96 & 2.54 & - & 42.74 & 4273.89 & 0.15 \\
\hline & & A & 200 & 150 & 43.96 & 2.36 & - & 36.29 & 1814.57 & 0.15 \\
\hline & & A & 150 & 68 & 43.96 & 2.17 & - & 30.66 & 2514.12 & 0.15 \\
\hline 9 & Tar & A & 336 & 250 & 9.33 & 2.70 & - & 9.63 & 828.14 & 0.10 \\
\hline 10 & Salt solution from EDU & A & 115 & 40 & 15.05 & 4.21 & - & 17.14 & 1285.61 & 0.80 \\
\hline \multirow[t]{2}{*}{11} & Crude oil & $\mathrm{B}^{* *}$ & 10 & 50 & 250.85 & 1.95 & - & 142.55 & 5701.96 & 0.10 \\
\hline & & B & 50 & 118 & 250.85 & 2.10 & - & 170.22 & 11574.78 & 0.10 \\
\hline \multirow[t]{3}{*}{12} & Desalted oil & $\mathrm{B}$ & 112 & 150 & 248.34 & 2.28 & - & 192.17 & \begin{tabular}{|l|}
7302.34 \\
\end{tabular} & 0.15 \\
\hline & & B & 150 & 200 & 248.34 & 2.47 & - & 214.40 & 10720.07 & 0.15 \\
\hline & & B & 200 & 214 & 248.34 & 2.65 & - & 231.36 & 3239.06 & 0.15 \\
\hline \multirow[t]{6}{*}{13} & Stripped oil to right coil of PS1 & B & 214 & 250 & 56.00 & 2.75 & - & 54.87 & \begin{tabular}{|l|}
1975.49 \\
\end{tabular} & 0.15 \\
\hline & & B & 250 & 300 & 56.00 & 2.84 & - & 59.75 & 2987.44 & 0.15 \\
\hline & & B & 300 & 371 & 56.00 & 3.18 & - & 66.73 & 4737.86 & 0.15 \\
\hline & Stripped oil to left coil of PS1 & $\mathrm{B}$ & 214 & 250 & 26.00 & 2.75 & - & 25.48 & 917.19 & 0.15 \\
\hline & & B & 250 & 300 & 26.00 & 2.84 & - & 27.74 & 1387.03 & 0.15 \\
\hline & & B & 300 & 310 & 26.00 & 2.97 & - & 29.42 & 294.16 & 0.15 \\
\hline \multirow[t]{6}{*}{14} & Stripped oil to left coil of PS1 & B & 214 & 250 & 64.00 & 2.75 & - & 62.71 & 2257.71 & 0.15 \\
\hline & & B & 250 & 300 & 64.00 & 2.84 & - & 68.28 & 3414.22 & 0.15 \\
\hline & & B & 300 & 370 & 64.00 & 3.18 & - & 76.17 & 5331.73 & 0.15 \\
\hline & Stripped oil to right coil of PS2 & B & 214 & 250 & 64.00 & 2.75 & - & 62.71 & 2257.71 & 0.15 \\
\hline & & B & 250 & 300 & 64.00 & 2.84 & - & 68.28 & 3414.22 & 0.15 \\
\hline & & B & 300 & 370 & 64.00 & 3.18 & - & 76.17 & 5331.73 & 0.15 \\
\hline 15 & Fuel oil heating in PS1 & B & 360 & 407 & 53.29 & 2.90 & - & 65.68 & 3086.84 & 0.15 \\
\hline 16 & Vacuum gasoil to HE24 & B & 15 & 87 & 43.96 & 2.10 & - & 25.64 & 1838.99 & 0.15 \\
\hline 17 & Water to EDU & $\mathrm{B}$ & 10 & 80 & 12.54 & 4.20 & - & 14.60 & 1021.87 & 0.80 \\
\hline 18 & Vapor overheating in PS1 & B & 135 & 450 & 1.05 & 2.69 & - & 2.60 & 819.88 & 0.60 \\
\hline 19 & Gas to pipe stills (fuel) & $\AA$ & 31 & 80 & 3.00 & 2.52 & - & 2.10 & 102.90 & 0.10 \\
\hline 20 & Fuel oil to pipe still (fuel) & $\AA$ & 49 & 80 & 3.79 & 2.05 & - & 2.32 & 71.80 & 0.10 \\
\hline
\end{tabular}

Notes: * A-hot flow.

** B - cold flow. 
ference in temperature between the heat-transfer media in the heat exchangers, because there is a crisscross heat exchange in the heat-exchange system (Fig. 2). Conversely, $\Delta t_{\min }$ represents the minimal temperature difference for the fully vertical heat exchange [9], for which the loads $Q_{H \min }$, $Q_{C \min }$, and $Q_{R E C}$ would reach the existing values. The intense crisscross heat exchange results not only in a considerable increase in the heat-exchange surface area, but also in significant heat transfer through the pinch, which is well seen in the grid diagram of the existing network of heat exchangers (Fig. 3).

In the existing system, 15 heat exchangers participate in this transfer, and flow 15 (below the pinch) uses a hot utility, which is inadmissible in energy-efficient chemical engineering systems.

Even the first introduction with the processing system revealed a significant potential of energy saving.

The calculated load on the utility system is $\sim 50 \mathrm{MW}$, and if we take into account the power withdrawn by flue gases, it is $\sim 20.4 \mathrm{MW}$; then, we can estimate the power released in fuel combustion in the pipe stills at $\sim 70.4 \mathrm{MW}$, or $\sim 36 \mathrm{~kg}$ of standard fuel per ton of refined oil.

Composite curves allow one to estimate the necessary heat-exchange surface area for a designed or retrofitted process with sufficient accuracy. For this purpose, using the measurement results obtained, we estimated the heat-transfer coefficients for each process flow (see table).

Further, using heat-exchange equipment prices reported by manufacturers, we can estimate the necessary capital investment and the period of the return on this investment. The cost of shell-and-tube heat exchangers is [8]

$$
\text { Capital cost }=A_{H E}+B_{H E}(S)^{c} \text {, }
$$

where $A_{H E}=\$ 5000 ; B_{H E}=\$ 120$; and $S$ is the heatexchange surface area, $\mathrm{m}^{2}$. For shell-and-tube heat exchangers, as a rule, $c=0.87$ [11].

The energy cost can be estimated from the market price of fuel oil of $\$ 112$ per ton at $\$ 87$ per kilowatt per year.

Using these values and composite curves, diagrams can be drawn for the determination of the dependence between $\Delta t_{\min }$, the investment in an additional area to the existing heat-exchange surface area, and the period of the return on investment of the proposed project (Fig. 4), from which an admissible $\Delta t_{\min }$ value can be found.

It can be seen that the problem of an energy-saving retrofit of the AVDU A12/2 unit is of a threshold nature, i.e., once a certain investment value is exceeded, the annual savings cease to increase (Fig. 4b). This threshold is at an investment of $\$ 2.23$ million, and the period of the return on investment is 0.82 year. The minimal difference in temperature between the heat-transfer media in the heat exchangers near the threshold value of energy consumption is virtually equal to $\Delta t_{\min }=20^{\circ} \mathrm{C}$.

The composite curves drawn for the considered operating mode of the unit at $\Delta t_{\text {min }} \approx 20^{\circ} \mathrm{C}$ (Fig. 5) show that cold utilities are virtually unused. The heat recuperation power in the heat-exchange system is doubled, and the power of the hot utilities is lower by a factor of 2.3.

At the found optimal $\Delta t_{\min }$ value, using pinch analysis methods, we synthesized a grid diagram for the project of retrofitting the heat-exchange system of the unit that lacks heat transfer through the pinch (Fig. 6). Constructed according to the grid diagram, the energy flow sheet of the retrofit project for the AVDU A12/2 unit (Fig. 7) has a lower heat power consumed by the process $(21.7 \mathrm{MW})$ and uses almost no cold utilities.

The heat-exchange surface area in the new heatexchange system should be increased by $19.5 \times 10^{3} \mathrm{~m}^{2}$, with its current value being $12.6 \times 10^{3} \mathrm{~m}^{2}$. It is this that requires capital investment for retrofit.

For the optimal arrangement of utilities, the pinch analysis uses the grand composite curve $[9,11]$, which indicates the energy requirements of the flow at any temperature from the temperature range characterizing the process flows.

Figure 8 presents the grand composite curve and the temperature profile of flue gases of the pipe stills of the unit. The point of intersection of the temperature profile and the ordinate axis indicates the temperature at which flue gases enter the chimney intake.

The power of the hot utilities shows the payload on the pipe stills, and the power of the cold utilities demonstrates the heat power withdrawn from the process (Fig. 8). The projection of the temperature profile of flue gases on the abscissa axis presents the power released during fuel combustion in the pipe stills. In the case of the existing heatexchange system of the process, the pipe stills release 79.8 MW, which is equivalent to the combustion of $9.3 \mathrm{t}$ of standard fuel per ton of refined fuel. After retrofitting the heat-exchange network of the unit according to the proposed project, e.g., for operation with a vacuum section in winter, no cold utilities are used and the power of the hot utilities becomes 2.71 MW. Because of this, the power released during fuel combustion in a pipe still is also lower, $Q_{H \min } \sim 32 \mathrm{MW}$, i.e., lower by a factor of 2.5 , which corresponds to the combustion of $3.72 \mathrm{t}$ of standard fuel per hour, or $15.5 \mathrm{~kg}$ of standard fuel per ton of refined oil (Fig. 8). Such a reduction in the fuel consumption by the pipe stills allows one to abandon the use of fuel oil as a fuel for the pipe stills and to heat the products in a single pipe still instead of two.

The slope of the temperature profile of flue gases is determined by the fuel consumption of the pipe stills [9]. The lower this consumption, the steeper the slope. For technological reasons, the temperature of the flue gases in the chimney intake upstream from the smoke stacks should not be below $300^{\circ} \mathrm{C}$, which determines the minimum possible fuel consumption by the pipe stills (Fig. 8). In this case, the power released in the pipe stills is $\sim 27 \mathrm{MW}$, which corresponds to the consumption of $3.13 \mathrm{t}$ of standard fuel per hour or $13 \mathrm{~kg}$ of standard fuel per ton of refined oil.

As the result of the retrofit, the specific fuel consumption by the process in the unit becomes $\sim 15 \mathrm{~kg}$ of standard fuel per ton of refined oil, which is lower than 


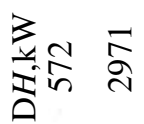

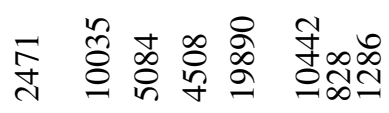
츤 근

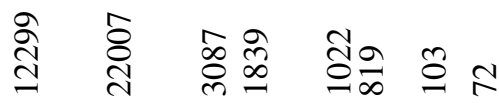

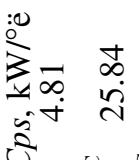

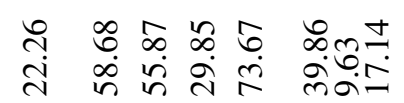

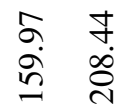
공

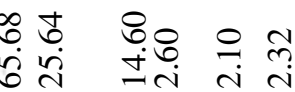

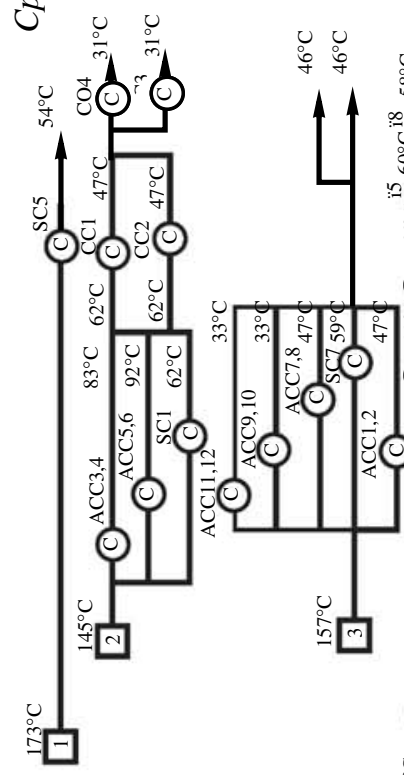

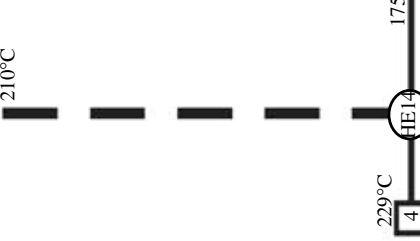




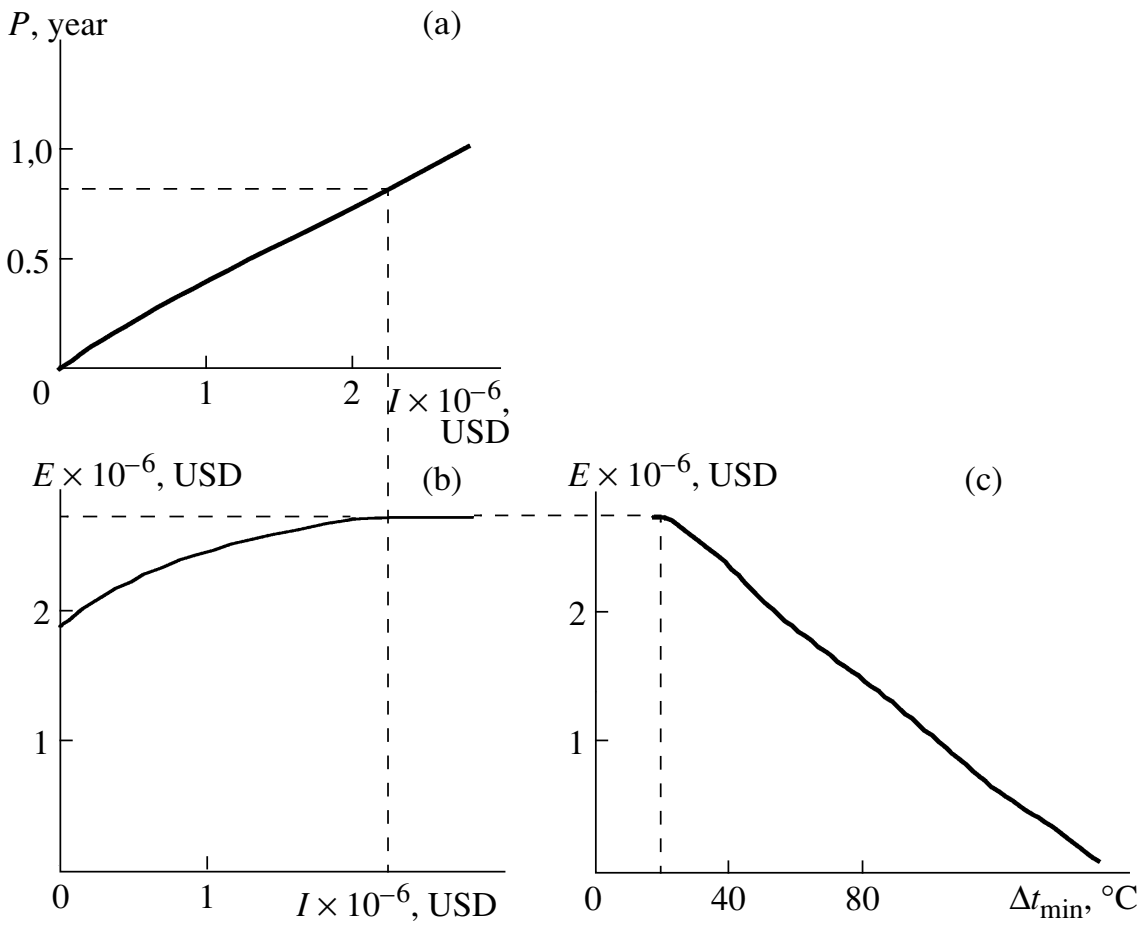

Fig. 4. Determination of the optimum $\Delta t_{\min }$ value according to the chosen criterion of retrofitting the heat-exchange system: (a) retrofit project return on investment period versus retrofit investment, (b) economic efficiency, and (c) annual profit versus $\Delta t_{\text {min }}$. The dashed line shows the relationship between the minimal temperature difference in the heat-exchange system, annual profit, project investment, and return on investment of the project.

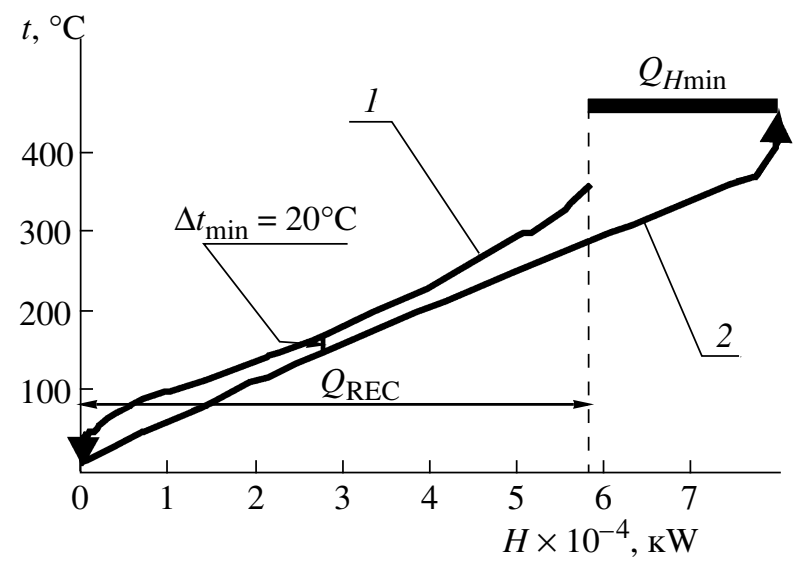

Fig. 5. Composite curves for crude distillation in the AVDU A $12 / 2$ unit for $\Delta t_{\min }=20^{\circ} \mathrm{C}\left(Q_{H \min }=21.7 \mathrm{MW}, Q_{R E C}=58.1 \mathrm{MW}\right)$ : (1) composite curve for hot flows and (2) composite curve for cold flows.

the current value by a factor of 2.4 , and if the reduction in emissions with flue gases and the decrease in their temperature downstream from the chimney intake are taken into account, then the specific fuel consumption for refining 1 ton of crude oil in the unit is $\sim 13 \mathrm{~kg}$ of standard fuel.

Fig. 3. Grid diagram for the existing heat-exchange system in the AVDU A $12 / 2$ unit, shown with the separation of process flows at the pinch. The dashed line represents the location of the pinch; $\mathrm{H}$, vapor heater; $\Delta H$, flow heat change, W; $\mathrm{C}$, cooling; ACC, aircooled condenser; PS1, PS2, existing pipe stills; SC, submerged cooler; HE1-HE34, heat exchangers; CO, cooler; CC, cooler-condenser. 


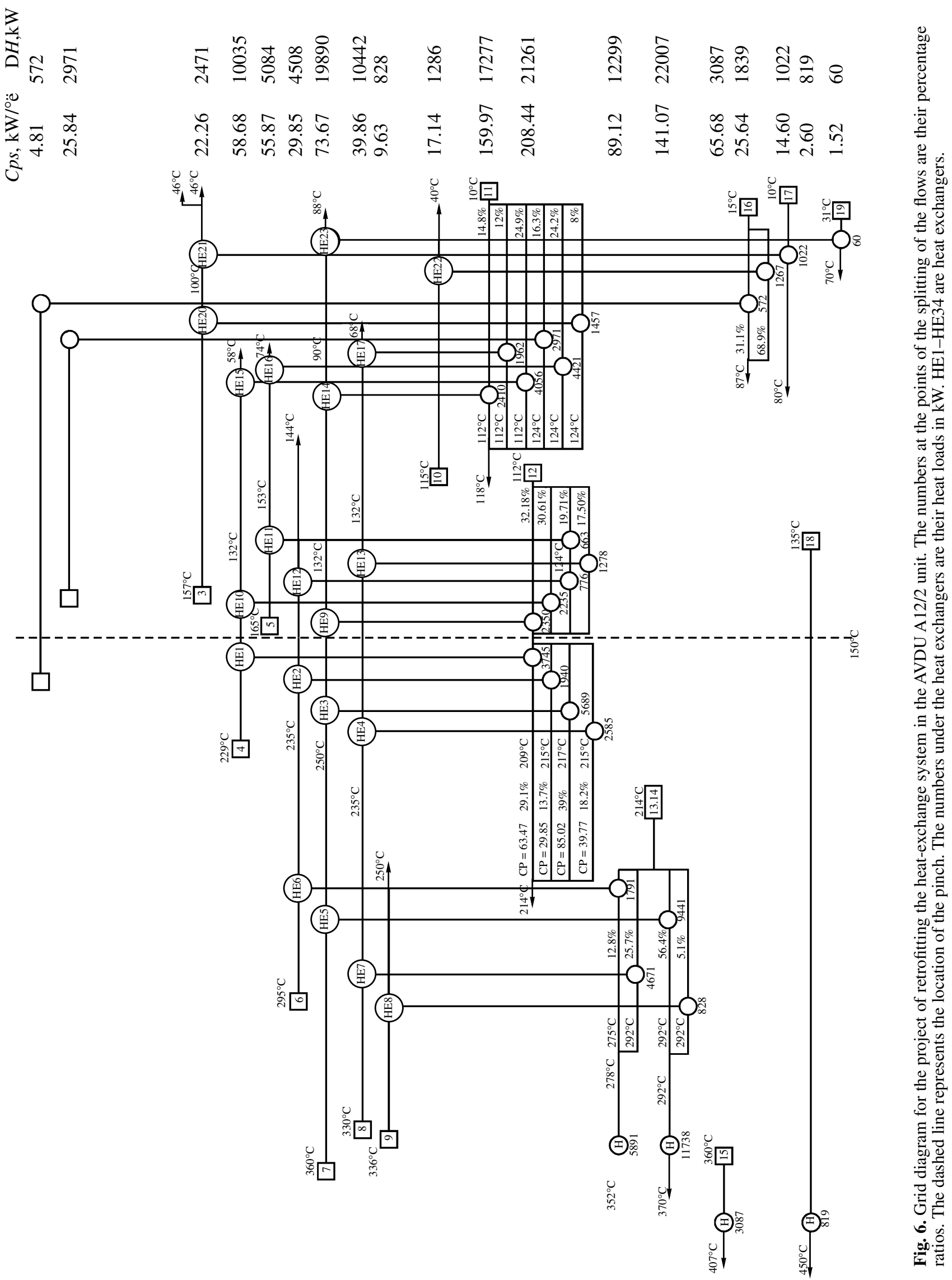




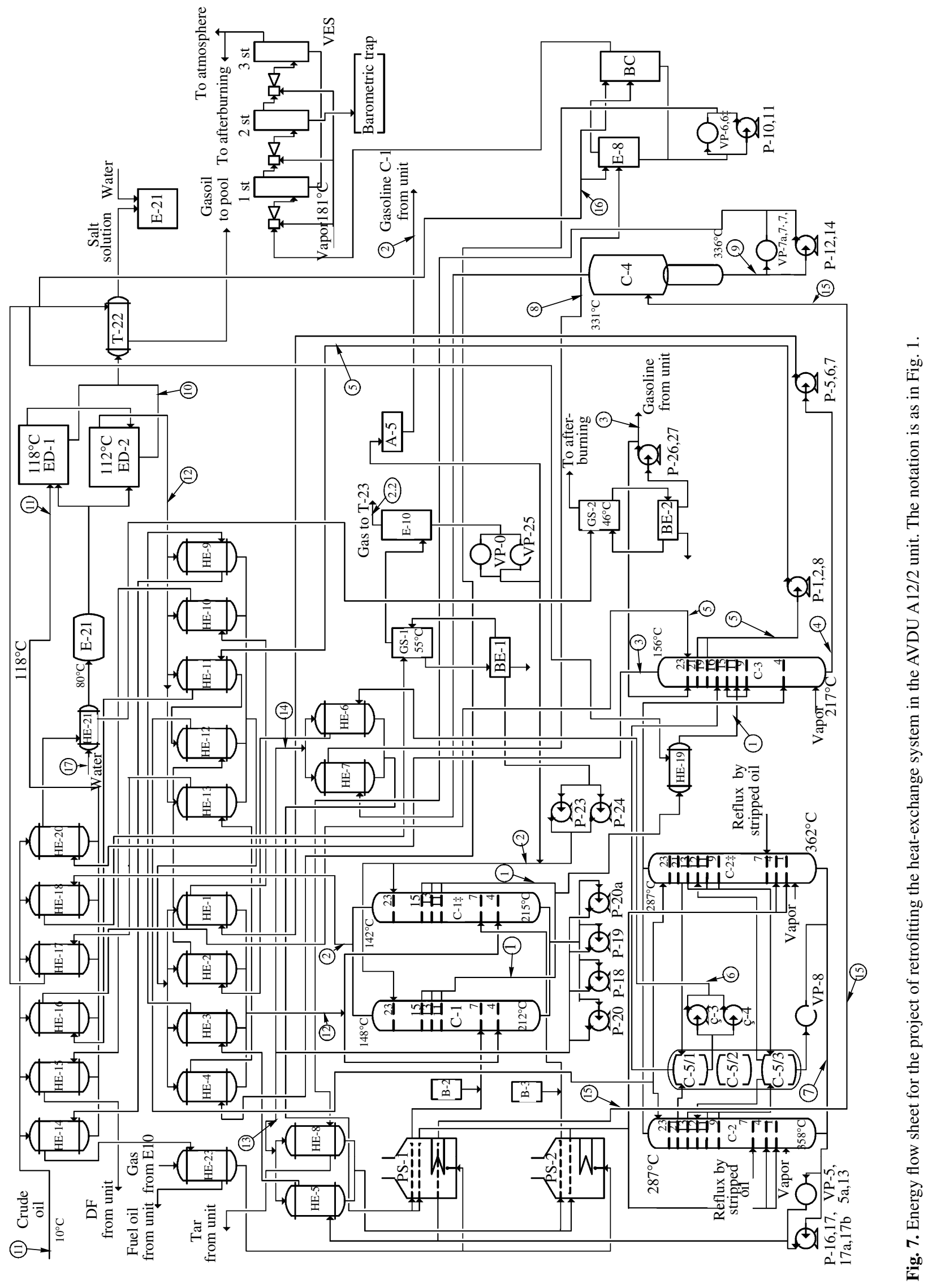


(a)

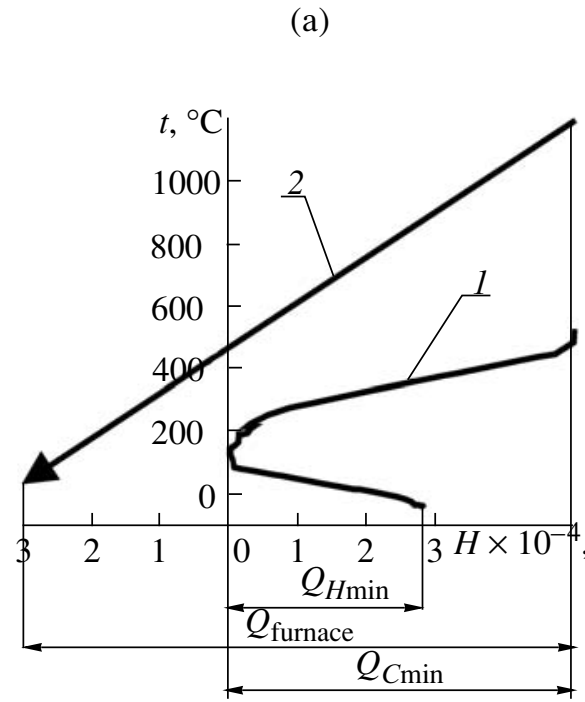

(b)

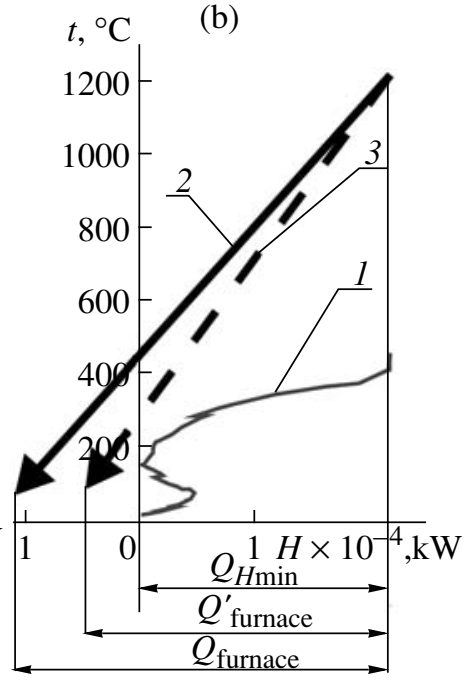

Fig. 8. Determination of the fuel consumption of the pipe stills by the pinch analysis: (a) for the existing heat-exchange system in the AVDU A12/2 unit and (b) for the proposed retrofit project; (1) grand composite curve for crude distillation, (2) temperature profile for flue gases from the pipe stills of the unit, and (3) temperature profile for flue gases from the pipe stills of the unit after reducing the temperature in the chimney intake.

\section{CONCLUSIONS}

Thus, after retrofitting the heat-exchange system for improving the thermal process integration in the system of process flows in the crude distillation unit, no more than $13 \mathrm{~kg}$ of standard fuel will be consumed per ton of refined oil, which is 3 times lower than that consumed currently. The period of the return on investment of the retrofit project will not exceed 8 months.

\section{NOTATION}

$A_{T}$-cost of the installation of a heat exchanger, $\mathrm{USD}$;

$B_{T}$-coefficient that is equivalent to the cost of $1 \mathrm{~m}^{2}$ of heat-exchange surface area, USD;

$C$-specific heat, $\mathrm{J} /\left(\mathrm{kg}^{\circ} \mathrm{C}\right)$;

$c$-coefficient that characterizes the nonlinear dependence of the cost of a heat exchanger on its heatexchange surface area;

$C_{P S}$-flow heat capacity (water equivalent), $\mathrm{W} /{ }^{\circ} \mathrm{C}$;

$E$-annual savings, USD;

$G$-mass flow rate, $\mathrm{kg} / \mathrm{s}$;

$H$-flow heat, W;

$\Delta H$-flow heat change, $\mathrm{W}$;

I-investment, USD;

$P$-payback period, year;

$Q_{\text {Cmin }}$ - power of cold utilities, W;

$Q_{H \min }$-power of hot utilities, W;

$Q_{R E C}$ - power of heat energy recuperation, W;

$Q_{\text {still }}$-power released in a pipe still, W;

$r$-latent heat of phase transition, $\mathrm{J} / \mathrm{kg}$;
$S$-heat-exchange surface area, $\mathrm{m}^{2}$;

$S t$-steam heater;

$t$ - temperature, ${ }^{\circ} \mathrm{C}$;

$t_{\text {cold }}$-temperature of pinch of cold flows, ${ }^{\circ} \mathrm{C}$;

$t_{\text {Phot }}$ - temperature of pinch of hot flows, ${ }^{\circ} \mathrm{C}$; ${ }^{\circ} \mathrm{C}$;

$t_{S}$-initial flow temperature (supply temperature),

$t_{T}$-final flow temperature (target temperature), ${ }^{\circ} \mathrm{C}$;

$\Delta t_{\min }$-minimal difference in temperature between heat-transfer media in recuperative heat exchangers, ${ }^{\circ} \mathrm{C}$;

$\alpha$-characteristic heat-transfer coefficient, $\mathrm{W} /\left(\mathrm{m}^{2 \circ} \mathrm{C}\right)$;

$\mathrm{A}, \mathrm{BU}, \mathrm{B}, \mathrm{E}, \mathrm{BE}$ - vessels;

ACC-air-cooled condenser;

AVDU—atmospheric/vacuum distillation unit;

$\mathrm{BC}$-barometric condenser;

$\mathrm{C} 1, \mathrm{C} 1 \mathrm{a}$ - atmospheric distillation columns;

$\mathrm{C} 2, \mathrm{C} 2 \mathrm{a}-$ columns for the distillation of stripped oil;

C3 - distillation column for the production of diesel oil;

C4-vacuum column;

C5-stripping column;

$\mathrm{CC}$ - cooler-condenser;

$\mathrm{CO}-$ cooler;

$\mathrm{CW}$-cooling water;

DF-diesel fuel;

ED-electric dehydrator;

EDU-electric desalting unit; 
GS—gas separator;

$\mathrm{H}$-heating of flows in Figs. 3 and 6;

HE1-HE34-heat exchangers;

$\mathrm{P}$-pump;

PS—pipe still;

$\mathrm{PW}$ - process water;

SC-submerged cooler;

VES-vapor ejection section;

$\mathrm{VP}$ - vapor pump.

\section{SUBSCRIPTS AND SUPERSCRIPTS}

Cmin-power of cold utilities that is required for the process;

$H$ min-power of hot utilities that is required for the process;

$H E$ - heat exchanger;

Pcold - temperature of pinch of cold flows;

Phot - temperature of pinch of hot flows;

$P S$-flow;

$R E C$ - recuperation;

$S$-initial flow temperature;

Still-power released during fuel combustion in a pipe still;

$T$-target flow temperature.

\section{REFERENCES}

1. Stepanov, A.V., Sul'zhik, N.I., and Goryunov, V.S., Ratsional'noe ispol'zovanie syr'evykh i energeticheskikh resursov pri pererabotke uglevodorodov (Rational Use of Raw and Energy Resources in Hydrocarbons Processing), Kiev: Tekhnika, 1989.

2. Stepanov, A.V. and Goryunov, V.S., Resursosberegayushchaya tekhnologiya pererabotki nefti (Resource-Saving Technology of Oil Refining), Kiev: Naukova Dumka, 1993.

3. Klemes, J., Kostenko, Yu.T., Tovazhnyanskii, L.L., Kapustenko, P.A., Ul'ev, L.M., Perevertailenko, A.Yu., and Zulin, B.D., The Pinch Design Method for EnergySaving Oil-Refining Plants, Teor. Osn. Khim. Tekhnol., 1999, vol. 33, no. 4, p. 420 [Theor. Found. Chem. Eng. (Engl. Transl.), vol. 33, no. 4, p. 379].

4. Ricci, G. and Bealing, C., Using an Integrated Approach Conserves Energy and Hydrogen, Neftegaz. Tekhnol., 2004, no. 3, p. 83.

5. Mallik, S. and Dhoul, V., Integrated Development and Plant Design, Neftegaz. Tekhnol., 2008, no. 4, p. 95.

6. Azimi, A.S., Klemes, J., and Ngatirin, S., Optimization of Heat-Exchange System for Crude Oil Rectification, Integr. Tekhnol. Energosberezh., 2003, no. 3, p. 97.

7. Promvitak, P., Siemanond, K., Bunluesriruang, S., Ragharentai, V., Retrofit Design of Heat Exchanger Networks of Crude Distillation Unit, Chem. Eng. Trans, 2009, Part 1, vol. 18, p. 99.

8. Promvitak, P., Siemanond, K., Bunluesriruang, S., and Ragharentai, V., Grassroots Design of Heat Exchanger Networks of Crude Distillation Unit, Chem. Eng. Trans., 2009, Part 1, vol. 18, p. 219.

9. Smith, R., Klemes, J., Tovazhnyanskii, L.L., Kapustenko, P.A., and Ul'ev, L.M., Osnovy integratsii teplovykh protsessov (Foundations of Heat Processes Integration), Kharkov: Izdatel'skii Tsentr NTU “KhPI”, 2000.

10. Smith, R., Chemical Process Design and Integration, Chichester: Willey, 2005.

11. Linnhoff, B., Townsend, D.W., Boland, D., et al., User Guide on Process Integration for the Efficient Use of Energy, Rugby: IChemE, 1991. 